\title{
Em busca dos sentidos políticos do Livro de Jonas: nova visão da geografia e a ficção profética como denúncia da história
}

\author{
In search of the political meanings of the Book of Jonah: \\ new vision of geography and the prophetic fiction as a \\ denunciation of history
}

\section{En busca de los sentidos políticos del Libro de Jonás: nueva visión de la geografía y la ficción profética como denuncia de la historia}

\author{
Prof. Dr. João Batista \\ Ribeiro Santos* \\ Profa. Me. Larissa Dantas \\ Camargo Mello**
}

Submetido em: 4-3-2021

Aceito em: 1-5-2021

\author{
* Universidade Metodista de São Paulo \\ Pós-doutor em História (História Antiga) na \\ Universidade Estadual Paulista (FCL/Unesp-Assis). \\ joao.ribeiro@metodista.br \\ (iD) \\ ** Universidade Metodista de São Paulo. \\ Bacharel em Teologia pela Universidade Metodista \\ de São Paulo. \\ dantaslarissa96@gmail.com
}

\begin{abstract}
RESUMO
O objetivo deste ensaio historiográfico é apresentar uma nova proposta para a leitura do Livro de Jonas na qual a pesquisa histórica traz à luz o sentido do itinerário geográfico do mapa mental elaborado pelos narradores e o gênero de ficção na profecia. No plano de fundo estão memórias de acontecimentos que justificam a denúncia, a saber, violências praticadas pelos grandes reinos, e que agora são representados na iconografia literária do livro pela Assíria e sua capital, Nínive. A denúncia, uma literatura profética ficcional em forma de panfletos, produzida vários séculos depois da queda do império neoassírio, tem função política em Judah no contexto das províncias sírias sob o império persa.

Palavras-chave: Livro de Jonas; ficção profética; Mediterrâneo antigo; Judah; Bíblia hebraica.
\end{abstract}

\begin{abstract}
The purpose of this historiographical essay is to present a new proposal for reading the Book of Jonah in which historical research brings to light the sense of the geographical itinerary of the mental map elaborated by the narrators and the genre of fiction in the prophecy. In the background are memories of events that justify the complaint, namely, violence practiced by the great kingdoms, and which are now represented in the literary iconography of the book by Assyria and its capital, Nineveh. The denunciation, a fictional prophetic literature in the form of pamphlets, produced several centuries after the fall of the Neo-Assyrian empire, plays a political role in Judah in the context of Syrian provinces under the Persian Empire. Keywords: Book of Jonah; prophetic fiction; ancient Mediterranean; Judah; Hebrew Bible.

\section{RESUMEN}

El propósito de este ensayo historiográfico es presentar una nueva propuesta de lectura del Libro de Jonás en la que la investigación histórica saca a la luz el sentido del itinerario geográfico del mapa mental elaborado por los narradores y el género de ficción en la profecía. Al
\end{abstract}


fondo se encuentran los recuerdos de hechos que justifican la denuncia, a saber, la violencia practicada por los grandes reinos, y que ahora están representados en la iconografía literaria del libro por la Asiria y su capital, Nínive. La denuncia, una literatura profética de ficción en forma de panfletos, producida varios siglos después de la caída del imperio neoasirio, juega un papel político en Judá en el contexto de las provincias sirias bajo el imperio persa.

Palabras clave: Libro de Jonás; ficción profética; Mediterráneo antiguo; Judá; Biblia hebrea.

\section{Introdução}

Esta introdução tem por finalidade aludir ao problema metodológico e, em seguida, ao que se pretende apresentar neste ensaio historiográfico. Os estudos acadêmicos atuais nos impõem algumas responsabilidades urgentes em relação à crítica e interpretação de camadas literárias (perícopes etc.) e livros da Bíblia hebraica. Os procedimentos exegéticos passam por profundas mudanças processuais e de significância. Com efeito, o tradicional modelo "histórico-crítico" ou "metodologia moderna", após mais de cinco décadas, tem sido sobreposto pelas "arqueologias". Elas começam a ser acrescentadas aos títulos e conteúdos de "exegeses". A mistura que pretende ser atualizadora pode colocar em risco o odre velho. Por quê? Porque ainda são raros os eventos que fazem parte de acontecimentos narrados na Bíblia hebraica com material arqueológico correspondente. (“Acontecimento" é um conjunto de eventos!). Com relação às responsabilidades aludidas, a questão de fundo não é a invenção de novos métodos porque os temos para encher bibliotecas; após o enciclopedismo dos métodos, a questão agora é a perícia.

Diante deste quadro, pretendemos apresentar o Livro de Jonas por meio de significativos elementos nele enunciados como uma obra do antigo Oriente-Próximo, com sua geografia mental e literatura profética ficcional em pesquisa histórica. As camadas literárias compiladas no "rolo" ou "livro" do profeta não exigem para si um lugar vivencial, trazem consigo regiões e movimentos vitais em suas molduras. Ou seja, remetem-nos ao imperialismo neoassírio e sua megalópole Nínive, a significativa parcela do judaísmo colonial persa, implicitamente à cidade de Jerusalém e seu culto a Yahweh, toda a costa do Mediterrâneo, particularmente às guarnições do exército da Assíria em incursões no Levante e aos mercadores de Tartessos.

$\mathrm{Na}$ ambientação histórica, buscar-se-á o sentido do itinerário geográfico; ficará demonstrado que os escritores desconhecem as rotas siro-eufratênias, mas conhecem muito bem o Mediterrâneo, para onde o profeta tem a intenção de fugir (nada se diz sobre os meios pelos quais ele se desloca e alcança a cidade de Nínive!). As camadas literárias na sua redação hebraica serão traduzidas e interpretadas, concluindo com algumas postulações teológicas acerca da denúncia do profeta, que entendemos ser o centro da sua profecia. 


\section{A ambientação histórica da geografia}

Não obstante o Livro de Jonas constituir-se numa obra compósita, ${ }^{1}$ apresentar um itinerário geográfico claramente mental e integrar a tradição mítica greco-romana em torno da cidade Nínive, ele mais do que sugere a necessidade de investigar as realidades que foram utilizadas como plano de fundo de sua literatura de ficção. O fato de seu protesto político estar carregado de sentido faz com que a camada redacional seja classificada como uma profecia do gênero historiográfico, não obstante sua narrativa fantástica. Em documentos palaciais do antigo Oriente-Próximo, é possível comprovar que o objetivo propagandístico justifica a forma de descrição literária de agente social, artefato e acontecimento mesmo quando estes são improváveis (SANTOS, 2013). No caso do Livro de Jonas, até a incontestável justificação foi desqualificada em favor do projeto sacerdotal de monoteísmo, no qual Yahweh deveria ser o deus universal.

Com efeito, a capital do império neoassírio tem sido considerada uma megalópole do antigo Oriente-Próximo; com testemunhos topográficos de assentamentos desde meados do terceiro milênio, a sua antiga condição de cidade-Estado justifica designá-la como uma "cidade hierárquica" do mundo siro-mesopotâmio, segundo a postulação de Brigitte Lion e Jean-Claude Margueron (2014, p. 122), pois a estatização de bens e serviços como o acesso à água e os benefícios da proteção física fazem parte das atribuições e são colocados sob a autoridade da elite governante.

Possuindo pelo menos quinze portas - se se considerarmos o império e a sua capital como centro do mundo, então tem-se a abertura para o universo fortemente justificada: o riggurat, os templos satélites, o panteão de divindades e o rei - mais as margens do rio Tigre, numa muralha retangular que protegia a cidade de cerca de 8.000 quilômetros quadrados e externamente, o acesso dificultado por uma vala de 45 metros de largura. Marc van de Mieroop (2020, p. 308) fornece uma síntese: após a morte do rei Sargon II (721-705), o rei Senaquerib (704-681) "restaurou completamente a antiga cidade de Nínive como sua capital. Ampliou-a a 750 hectares rodeada por um muro de 12 quilômetros, e construiu duas cidadelas com edifícios públicos, também decorados".

O fato de Nínive não ter mais desempenhado qualquer função relevante na política regional da Mesopotâmia após o ano 612, quando a coalizão entre os medos e babilônios a conquistou, faz com que as menções a ela nas quais fora reconhecida como capital imperial sejam datadas até o período da dinastia iniciada por Aššurbanipal (668-631/627), numa estrutura de temporalidade civilizatória de média duração entre os anos 668 a 612 . Desta forma, a partir do século VI, quando as elites judaítas sobreviventes no exílio da Babilônia e em seguida, no século V, quando as elites da cidade

\footnotetext{
Todas as citações bíblicas deste ensaio têm por referência a BHS (ELLIGER; RUDOLPH, 1997).
} 
de Jerusalém (escribas e sacerdotes) forjam o "novo Israel" e o judaísmo, as textualizações de memórias, tradições e descrições de testemunhos devem ser consideradas como retroprojeções.

No quadro de autores clássicos a tomar uma metrópole como símbolo do que deseja protestar, destaquemos na Bíblia hebraica os escritores do Livro de Jonas e os profetas do Livro de Nabum, especificamente na Antiguidade Clássica. Afora o poeta do capítulo 2 do Livro de Jonas, ${ }^{2}$ todos demonstram odiar a capital refundada pelo rei Senaquerib e o império neoassírio pelas violências praticadas contra as populações autóctones do Levante, onde as deportações são apenas um dos seus muitos procedimentos; ${ }^{3}$ por isso se pode notar nos enunciados certos motivos de contentamento por sua queda. A decadência e ruína de Nínive nas camadas literárias do Livro de Nahum ${ }^{4}$ são um ícone repleto de sarcasmo, elaborado com escárnio e sátira muito a posteriori e por causa da queda do império, em 612. Há, inclusive, informação por algum dos autores dos capítulos 1 e 3-4 do Livro de Jonas de registro censitário oficial; sabe-se que a "grande cidade" possui "cento e vinte mil seres humanos ['ädàm]".

A história tradicional do antigo Israel destacou nas relações diplomáticas do rei Salomão os centros comerciais que por sua importância permaneceram na memória coletiva por longuíssima duração, chegando aos historiógrafos gregos e romanos. Este é o caso do destino da embarcação tomada pelo profeta Jonas. Narrativas lendárias sobre o sucessor de Davi em 1Reis 9.2628, com estaleiro nas terras de Edom entre o mar Morto e o mar de Suf (mar Vermelho), e 1Reis 10.22, com ocupação portuária no norte do mar Mediterrâneo; além disso, uma glosa certamente judaica, em 1Reis 22.49-50, retroprojeta uma informação acerca da cidade de Tarsis ao século IX para colocar numa tentativa de acordo comercial o rei judaíta Josafat e o rei israelita Ahaziah, sucessor de Ahab. A localização já à época seria mental, e atualmente o debate geográfico pleiteia desde a Espanha meridional à Cilícia.

Em divisão mental da geografia do mundo entre mar e terra, Tarsis, nesse caso, seria Tartessos, representaria uma das partes extremas da terra, no Mediterrâneo ocidental (DAY, 2012). Até aqui, estamos no perspectivismo simbólico da mentalidade de entroncamentos comerciais adotada por escritores da Bíblia hebraica, baseados em tradição oral de localidades costeiras que lhes são bem conhecidas, tais como Creta/Caftor, Rodanim, Yawan, Líbia/Put e Lídia/Lud.

A retórica em torno de Salomão é de engrandecimento de Judah num período em que aquele pequeno reino vivia sob a sombra do reino de Israel

\footnotetext{
2 Recentemente realizamos uma análise histórico-literária do capítulo 2 do Livro de Jonas (SANTOS; COSTA; CAMARGO; SILVEIRA, 2016).

Por exemplo, Nahum 3.1-7.

Veja especialmente Nahum 2.10-11 e 2.13-14.

Jonas 4.11 .
} 
Norte, mas em relação ao Livro de Jonas serve como indicador de evidências da vocação de comércio fluvial e marítimo a que se desejam para Judah e da lógica adotada para o mapa geográfico da fuga do profeta. Com efeito, até mesmo o redator final do livro falha por não corrigir o equívoco dos escritores das camadas literárias. John Day (2012, p. 360), com muita ironia, nota que Jonas ao fugir de Yahweh por negar-se a pregar aos ninivitas:

subiu em uma barca em Jope indo para Tarsis, longe da presença do Senhor. Nínive, a capital da Assíria, obviamente ficava ao nordeste de Israel, e se Jonas estivesse indo para Tarsus, ele na verdade estaria mais perto de Nínive do que se tivesse ficado em Jope!

Precisamos consertar a rota! Outra lógica consiste em pensar nas várias rotas com serviço disponível no porto. Tarsis, por quê? Para dar sentido ao itinerário da fuga do profeta, seria necessário considerar a divisão do mundo proposta pelo poeta do Salmo 72, cujos versículos 8-11 parece terem sido copiados de uma inscrição de cerca de 671 do rei assírio Eššarhaddon (680669), que tem em vista a manutenção da submissão de regiões comercialmente produtivas, conectando Chipre a Tartessos como dois limites levantinos no mapa do antigo Oriente-Próximo (LIPIŃSKI, 2010; DAY, 2012).

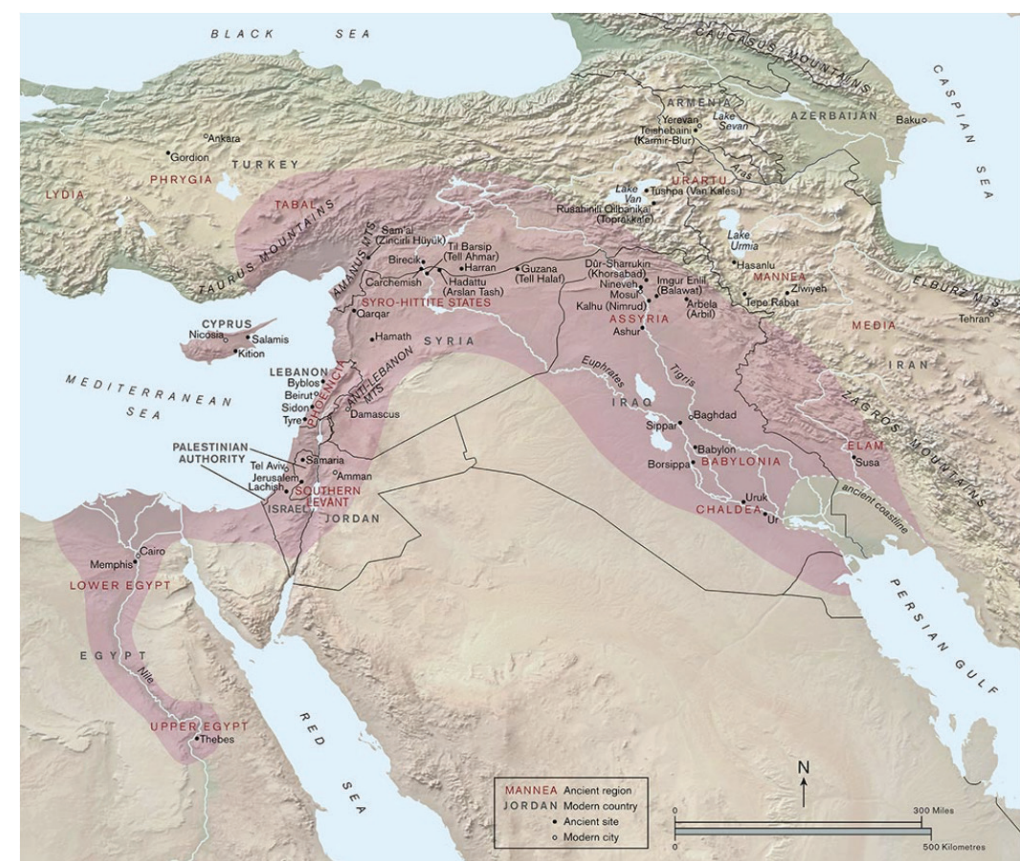

Figura 1. Mapa do império neoassírio durante o reinado de Aššurbanipal (668-631/627) (https//blog.britishmuseum.org/introducing-theassyrians/) 
Especificamente a região sul do Levante já havia sido provincializada na década de quarenta do século VIII. Isto é, o local referencial da citada cidade de Tarsis, de acordo com Day (2012, p. 366), é a cidade de "Tartessos na Espanha, não Tarsus na Cilícia”, sem, no entanto, ignorar outras variantes para a locação mapográfica da cidade principalmente pelos indícios de que o nome fora aplicado a vários locais na costa do Levante.

Demasiado importante era o consumo de objetos luxuosos na capital assíria; afora as obras de arte, encontramos listas de mantimentos comestíveis de primeira qualidade, como a importação de “azeite fino" (İ.GIŠ DÙG.GA, šamnu țābu) do norte da Síria, mel vermelho e vinho branco, vinho das montanhas cintilantes de neve, vinhos da Anatólia e do Líbano, carregamento de produtos alimentícios ("incluindo gafanhotos, caça, romãs, bolos e plantas"), chefes de cozinha especialmente qualificados para grandes celebrações nos templos e no palácio real, artistas para registros pictográficos, relevos escultóricos e murais de cenas de conquistas e celebrações em grande escala no Palácio Norte de Aššurbanipal (THOMASON, 2004, p. 153).

Destarte, a importância das culturas demonstra uma função específica do poder da Assíria: a difusão do saber acadêmico - um primoroso exemplo é a biblioteca do rei e bibliófilo Aššurbanipal em Nínive, que contava entre seus mais de vinte mil tabletes com obras babilônias raras - e das obras de arte dispõe os espaços reais ao público, em que os templos conciliavam as atividades cúlticas com atividades escribais e o rei - referimo-nos a Senaquerib - também produzia joias.

Resta-nos ainda a representação de presença literária da cidade de Ofir, pois o trajeto tradicional alocado no reino de Judah justifica-se pela especialização dos empreendimentos metalúrgicos no vizinho Edom. Seguindo a pesquisa de Edward Lipiński (2010, p. 266), Ofir não era uma imagem para ilustrar lendas salomônicas, um ostracon encontrado em Tell Qasile, assentamento urbano fundado no século XII pelos filistitas próximo a Tel Aviv e cerca de 2 quilômetros do mar Mediterrâneo, atesta "a Casa de Hiram" (l-Byt Hrn $)$ como elite governante local e evidenciando relações desses líderes tribais com Judah. No entanto, isso não indica necessariamente o comércio de metais com Judah, pois os mercadores de Ofir utilizavam os serviços portuários de Tell Qasile para comercializar nas cidades do Mediterrâneo, ao invés de acessar o Golfo de Áqaba, o mar de Suf para chegar nas terras de Edom e Judah. Podemos dizer que em questão de escalas de longo curso, tanto no caso de Salomão quanto no de Jonas, as nuvens de ficção nunca se dissiparam das histórias contadas. 
Por outro lado, nunca estaremos diante de simples movimentos nacionalistas na província persa de Yehud ou especificamente na cidade de Jerusalém. No caso de Jonas, os panfletos são políticos num plano de fundo da religião de Yahweh que justificam a celebração pela queda do império, a despeito de vozes que invocam uma momentânea preservação da capital ecoarem sentida tolerância.

Jonas viaja para o fim do mundo! (Ou cruza o Mediterrâneo de ponta a ponta?) Ele se recusa a pregar salvação em Nínive, capital do império neoassírio. Por outro aspecto, entre a megalópole mesopotâmia ${ }^{6}$ e a Tartessos, a metrópole comercial levantina e seus comerciantes fenícios, num quadro em que ambas as cidades simbolizam, como postulou Lipiński (2010, p. 268), "a universalidade do poder real", o profeta daria preferência pelos fenícios. Por trás das palavras, há resistência a uma translação radical de culturas siro-eufratênias - a liberdade tem limites nas novas comunidades religiosas judaicas! E não podemos nos descuidar de que essa escolha também é outra forte ironia contra Jonas se se pensar nas interpretações dos historiógrafos deuteronomísticos condenando a dinastia omrida e todo o Israel Norte por causa das suas relações diplomáticas com a Fenícia.

\section{A ficção literária profética}

A redação das camadas literárias da profecia de Jonas situa-se nesses contextos retroprojetados, propondo a sua recepção dos acontecimentos pelas comunidades judaicas como se fossem históricos. Ou seja: o conjunto redacional a que chamamos de livro intenta ganhar sentido para além da ficção, e é isto que será apresentado na análise literária.

O profeta (nābî̀ Yônāh) de origem colonial que inicialmente recusa a ordem de Yahweh para anunciar a salvação na capital do império. O "rolo" ou "livro" é uma compilação de panfletos, com apenas quatro pequenos capítulos e conteúdo dividido em duas partes com duas subdivisões cada: o bloco do capítulo 1, que contém os dois primeiros capítulos (1 e 2) e o bloco do capítulo 3, que contém os dois últimos capítulos (3 e 4). Cada um dos dois blocos possuem a mesma fórmula inicial: "E aconteceu a palavra de Yahweh a Jonas".

\footnotetext{
6 Consideramos razoável sublinhar que as relações entre os grandes reinos do antigo Oriente-Próximo tinham períodos de amistosos tratos diplomáticos e até trocas de gentileza, disto temos testemunhos na correspondência de Tell El-'Amarna. Para situarmo-nos no contexto da nossa pesquisa, no século VII, é exemplar a admiração demonstrada por reis assírios em relação às obras de arte egípcias (THOMASON, 2004).
} 


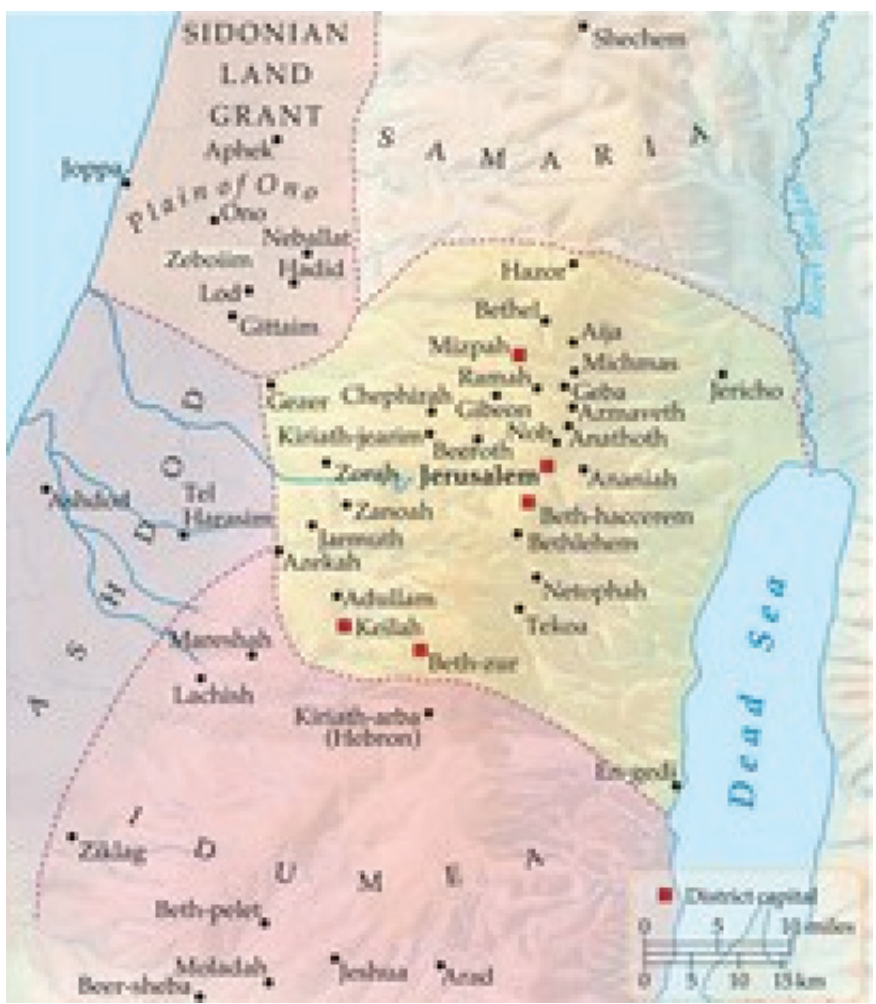

Figura 2. Mapa da província de Yehud, período posterior ao exílio na Babilônia (biblestudy.org)

Os dois primeiros capítulos se desenvolvem no cenário do mar: Jonas recebe a ordem divina de ir anunciar a mensagem à cidade de Nínive. Em vez de atender à ordem e seguir, o näb̂̀' empreende uma fuga marítima e vai na direção oposta, à cidade de Tarsis. Durante o percurso da viagem, a barca ('aniyyāh) é assolada por uma tempestade forte que coloca em risco a vida de todos os tripulantes. Após o esforço frustrado de apaziguar os danos da intempérie, os marinheiros "lançam a sorte" com o objetivo de entender a causa da tormenta. A sorte cai sobre Jonas, que após revelar sua origem e motivo da fuga, relata aos homens a solução para que a tempestade cesse: ele teria de ser lançado ao mar. Assim acontece: a tempestade cessa e Jonas, no mar, é engolido por um grande animal marinho, onde permanece por "três dias e três noites".

Os dois últimos capítulos do segundo bloco têm por cenário a terra: após ter sido vomitado pelo animal, a palavra de Yahweh acontece novamente a Jonas, que dessa vez obedece e vai à cidade de Nínive. O anúncio panfletário do profeta, uma síntese profética de discurso de controvérsia, tem impacto 
imediato na população ninivita que, após um decreto real, entra em jejum e se converte a Yahweh (na verdade, na compilação textual a informação acerca do decreto é posterior à reação da população).

Ao ver o arrependimento dos ninivitas, Yahweh também se arrepende do mal que iria fazer à cidade, revelado por Jonas. Após a conversão em massa e do anúncio bem-sucedido por gerar arrependimento, Jonas se retira da cidade para ver os desdobramentos da profecia. Enfurecido com a misericórdia divina por ter preservado a cidade, Jonas contesta a Yahweh: admite que a causa de sua fuga inicial foi justamente por saber que Yahweh é um deus misericordioso e clemente. Após o diálogo entre Yahweh e Jonas e após episódios didáticos (BAKKER, 2010) que têm a intenção de ensinar ao próprio profeta questionador e enfurecido, o livro é concluído com uma questão demográfica que reafirma a importância da megalópole.

\section{Datação e autoria}

A data de composição do livro envolve um conjunto de incertezas que superam qualquer dado histórico indiciário e de linguagem. Nem sempre a questão da datação do livro esteve em pauta acadêmica, mas ganhou força e começou a suscitar debates e revisões na segunda metade do século XX da nossa Era, quando a crítica literária começou a inquirir sobre o assunto. Com a aplicação da crítica literária, de caráter histórico-crítico, a redação final do livro foi sendo progressivamente posicionada para o período assim chamado pós-exílico (BAKKER, 2010).

Há uma conexão e uma referência entre o personagem "Jonas" do Livro de Jonas e o nābî̀ Yônāh de 2Reis 14.25, também referenciado como filho de 'Amittay, que pertenceu à tribo de Zebulun e viveu na cidade de Gat-Hefer, na época em que o rei Jeroboam II (783-743) reinava em Israel Norte (LIMBURG, 1993). No entanto, associá-los como sendo a mesma personagem histórica, e assumir o personagem de 2Reis como o autor e personagem do Livro de Jonas implica em sérios problemas. Sobre isto, Luís Alonso Schökel e José Luiz Sicre Díaz (1991, p. 1007) afirmam:

Amitai de 2 Re 14.25 não tem nada a ver com o protagonista do nosso livro; durante o reinado de Jeroboam II, Nínive não era a capital da Assíria. Além disso, o livreto de Jonas parece muito influenciado por Joel e Jeremias, que são profetas posteriores ao século VII. Por outra parte, a interpretação histórica encontra obstáculos intransponíveis do ponto de vista arqueológico (a dimensão extraordinária de Nínive), zoológico (o "grande peixe" mediterrâneo) e da história das religiões (Nínive nunca se converteu). 
Além das postulações contrárias à interpretação tradicional de "javeização” da capital do império neoassírio, Alonso Schökel e Sicre Díaz afirmam a ausência de evidência quanto a uma relação histórica entre o autor do Livro de Jonas e o nābî' Yônāh de 2Reis 14.25. Isso representaria uma datação tardia, certamente no período pós-exílico, atestado pelo uso de termos que parecem ser aramaísmos, comuns em textos da época, quando a língua hebraica já tinha sido influenciada pelo aramaico (BAKKER, 2010). Além de termos e expressões ${ }^{7}$ indicarem um uso posterior, há a presença de costumes persas ${ }^{8}$ e correlações entre vocábulos que só podem ser encontrados em redações tardias da Bíblia hebraica, como os livros das Crônicas e Eclesiastes (WOLFF, 1986). Mas também encontramos semelhanças literárias entre o Livro de Jonas e textos com processos de escrituração iniciados no exílio babilônio, além de redações judaicas nos livros dos Salmos, 1Reis e Ezequiel (FEUILLET, 1947).

Sendo assim, se observarmos todas as considerações expostas: como as questões arqueológicas, o uso de termos aramaicos, a presença de costumes persas, as correlações entre vocábulos com textos tardios da Bíblia hebraica e as semelhanças literárias com outros textos dos períodos exílico e pós-exílico, podemos datar o Livro de Jonas entre os séculos IV e III (WOLFF, 1986), fim do período persa e início do período helenístico.

\section{Sentidos de historicidade na fiç̧ão profética}

Como vimos, há uma série de problemas que se coloca na correlação entre o personagem da narrativa de 2Reis 14.25 e o autor e personagem do livro que faz parte do Rolo dos Doze Profetas. Portanto, não existe uma referência precisa que possibilite identificar definitivamente ambos como sendo o mesmo profeta e, portanto, que afirme a existência de um autoptes, o autor-testemunha ocular dos acontecimentos narrados. Destarte, o livro é inteiramente composto em terceira pessoa, com poucos momentos em que o nāb̂̀ fala por si, e há ainda, permeando o texto, um tom satírico nas descrições acerca da personalidade de Jonas que faz com que seja pouco provável que o autor esteja falando sobre si próprio.

Para melhor compreensão do autor e do lugar histórico do trabalho escribal, podemos levantar perguntas acerca do destinatário do manuscrito: Para quem o rolo foi escrito? Qual era o objetivo do manuscrito? Nelson Kilpp (2008) compreende que o Livro de Jonas possui caráter didático, procura

Por exemplo, hannūn warahūm, "misericordioso ["piedoso", "gracioso"] e clemente ["misericordioso"]".

8 Bakker (2010) aponta para a participação dos animais no jejum e o decreto introduzido tanto pelo rei quanto pelos nobres. 
transmitir um ensinamento, uma lição. Se assim o for, os escritores ou redator do livro podem se encontrar entre aqueles que exercem atividade docente, seja em ambiente sacerdotal ou acadêmico.

José Ademar Kaefer (2019) indica a existência de dois grupos conflitivos em Jerusalém no período pós-exílico: os judeus que defendiam uma maior abertura às outras culturas, com uma educação heterogênea e com a participação dos estrangeiros e os judeus nacionalistas, que se opunham à presença de estrangeiros e eram centrados no templo. Assim, o segundo grupo seria representado pelo próprio profeta nas cenas de protesto contra a Assíria, sectário com o estrangeiro e voltado ao templo, ${ }^{9}$ sendo que a mensagem final do livro demonstra a possibilidade de superação do ódio e o chamado ao arrependimento:

Os judeus do pós-exílio são desafiados a levantar-se acima de sua antipatia e a ver o mundo através dos olhos de seu Deus Criador cujo cuidado e a piedade é tão grande quanto seu poder. Também os gentios têm obrigação de obedecer a lei moral de Deus. A audiência seria pedida para ponderar um crivo teológico: o que aconteceria com a maldade dos estrangeiros, se Nínive não tivesse se arrependido? A providência primordial de Deus é preservar a vida humana e animal, não destruí-la. (BAKKER, 2010, p. 23).

Dessa forma, o conteúdo didático se estabelece no contraste entre o profeta de características nacionalistas, à semelhança com os livros de Esdras e Neemias, e uma comunidade ou grandeza socioétnica, ou ainda uma cidade, que apesar de ser estrangeira, está atenta às palavras proféticas de Yahweh e que se arrepende de ações que resultaram na morte de pessoas. Como resultado do arrependimento comunitário, Yahweh se compadece e poupa a cidade da destruição.

\section{A forma ficcional como gênero literário}

Compreender o gênero literário de uma obra é atitude importante para que haja uma maior compreensão da obra e uma aproximação entre o leitor e o objetivo da redação textual. O livro do nābî' Yônāh vem sendo atribuído a um extenso leque de possibilidades do gênero literário:

Diversas propostas de classificação do livro de Jonas foram empreendidas nas últimas décadas. Tais tentativas abrangem um conjunto bastante diversificado de teorias, que podem ser assim expressas: alegoria, biografia, conto, ficção didática, história, historieta satírica com força parabólica, lenda, midrash, mito, narrativa didática, narrativa profética, novela, parábola, paródia, sátira e tragédia. (VAILATTI, 2018, p. 31-32).

9 Shawn W. Flynn (2020) explica que podemos perceber a teologia do templo no capítulo 2 do Livro de Jonas. 
Tal variedade de classificações já aponta, por si só, para a complexidade e peculiaridade do livro. Percebemos que muitas das classificações enunciadas por Vailatti (2018) escapam ao caráter religioso, unicamente, como por exemplo a ficção didática, a novela e a biografia. Compreender um texto bíblico como literatura apresenta alguns obstáculos estruturais: muitas vezes, os textos bíblicos são compreendidos unicamente à luz da instituição religiosa e não como resultado da cultura e como representante de complexos culturais. Há, assim, uma exclusão da polissemia textual, da oscilação das personagens e das tramas, pela qual a mensagem assume significado puramente confessional e abandona qualquer possibilidade de ser entendida num contexto de estudo. Há necessidade de articulação entre ambos os contextos: o religioso e teológico e o literário. Assim:

(...) é importante identificar a relação entre narrativa literária e modos teológicos, quer dizer, o literário da Bíblia não pode ser compreendido em profundidade sem que se leve em consideração que a narrativa é constituída por concepções religiosas e teológicas. Neste caso, é mais importante o campo de relações entre religião/teologia e literatura que a visão de causa e efeito, segundo a qual ou a genialidade estética criaria a religião ou a religião, quase que por acaso, criaria a literatura. Não é possível nem desejável estabelecer uma diferença abissal entre o que é teológico e o que é literário na Bíblia, pois os âmbitos se confundem, interagem de forma densa e complexa. Seria a mesma coisa se quiséssemos estabelecer a diferença nítida entre mito religioso e mito literário em Homero. (...) é importante considerar o texto dentro de uma complexa totalidade artística permeada de sutilezas e economia de detalhes. Os textos bíblicos são sucintos, quando comparados a outros considerados fundamentos da literatura ocidental, como é o caso dos textos de Homero. (...) ao contrário da leitura estritamente teológica, (...), a linguagem bíblica é também literária no sentido de ser marcada pela tensão e oscilação de personagens, o que sugere que estas podem crescer, serem alteradas no decorrer das narrativas. Em vez da imutabilidade de um Deus, o que temos é um personagem constante, mas mutável. (MAGALHÃES, 2008, p. 18).

Percebemos que há mais de uma característica que aponta para a Bíblia como literatura: a narrativa é constituída de elaborações religiosas, teológicas, com articulações estéticas, há presença de tensão e oscilação de personagens e um Deus, que apesar de constante é mutável, exatamente como acontece no caso do Livro de Jonas. Temos, ainda, os três elementos fundamentais da comunicação artística: o autor, a obra e o público (CANDIDO, 2006): o autor como pertencente à classe dos sábios e sacerdotes, a obra representada pelo livro e o público, como os judeus sectários que, representados por Jonas, desconheciam o caráter de Yahweh, especificamente a sua misericórdia.

Tomando em conta todos esses postulados críticos em relação ao livro e interpretando com as pesquisas sobre a datação e autoria em suas várias 
etapas, podemos assumir o Livro de Jonas pelo prisma do gênero literário da novela, que recebeu uma importância especial na Antiguidade Clássica, juntamente com o teatro e as encenações de tragédias, escárnios, cânticos fúnebres, sarcasmos etc., cuja as qualidades se encaixam com aquelas encontradas no livro: geralmente, a trama novelística bíblica se encontra no tempo passado, ou seja, é retrospectiva, situa-se em outro território ou meio ambiente diferente do lugar do narrador, se apropria de variados elementos pretéritos e elementos presentes com o objetivo de conduzir a uma transformação do contexto histórico em que foi escrita (KAEFER, 2019).

O enredo novelístico bíblico se desenvolve em três etapas: tensão, intensificação da tensão e solução (SILVA, 2007): tensão, exemplificada pelo chamado e fuga do nāb̂̀'; intensificação da tensão, como Jonas no ventre do animal marinho e sua resposta positiva ao segundo chamamento divino; e solução, como os ninivitas arrependidos, Yahweh arrependido e Jonas levado a questionar-se pela divindade.

Por fim, a redação desses panfletos rapidamente se tornou emblemática das lutas de sobrevivência de grupos excluídos socialmente pelas elites governantes sacerdotais, ao mesmo tempo em que Nínive e Babilônia eram transformadas em entidades míticas - a compilação em vários "rolos" ou "livros" faz parte do processo de preservação e serve à docência pública.

\section{Moldura teológica para o protesto}

A estrutura da pesquisa histórica foi seguida pela interpretação literária crítica, ambas metodologicamente comparativas. Mas o livro profético está repleto de teologias; essas teologias são os pilares de sustentação da ficção profética demonstrada como redação de gênero novelístico. Pois bem, a teologia faz parte da história social, por isso, permanecemos nos contextos do antigo Oriente-Próximo.

Ao final, no plano da mudança utópica da sociedade ninivita atribuída ao temor do rei a Yahweh e à credibilidade do anúncio panfletário de destruição da cidade - na verdade, o que temos é enunciado - fica destacada a ação comunicativa. A comunicação profética é peculiar porque é indireta, ${ }^{10}$ e as informações daí decorrentes mantêm o padrão do livro, são anônimas, apesar de terem pontos de gravidade quando emergem de uma terceira camada

\footnotetext{
10 Talvez por lapso ou por exclusiva opção, os narradores ao retroprojetarem as cenas para a capital do império deixaram de conectar o profeta ao rei. Como demonstra Martti Nissinen (2017, p. 289-292), a comunicação direta é muito comum no antigo Oriente-Próximo, também na Bíblia hebraica.
} 
literária: ${ }^{11}$ soube-se por meio desconhecido que o rei assírio, cuja identidade se desconhece, teve conhecimento da profecia por intermédio de alguém igualmente não nomeado. Interessa mais o perspectivismo teológico inicial: no conjunto textual do livro fica subsumido um certo desejo de universalidade de Yahweh quando os tripulantes da barca sabem naturalmente do caráter da divindade, inexistem no diálogo controvérsia identitária e ignorância, posto que são eles os orantes de Yahweh. ${ }^{12}$

A universalidade do poder real ficou questionada diante da apresentação de um deus que criou céus, terra e mar, ou seja, todos os domínios geográficos do rei. $\mathrm{Na}$ barca, o entendimento de Jonas acerca da divindade faz com que ela seja perceptível no lugar; na cidade, o rei torna-se submisso ao anúncio de Yahweh. Esse movimento construído pelos narradores, que insistem em fazer com que Jonas perceba seu deus em articulações horizontais e verticais conflituosas, foi notado por Shawn W. Flynn (2020, p. 170-78). Com o predomínio designado a Yahweh no livro, fica revelada, especialmente no capítulo 4, a complexidade do caráter de Jonas. Em síntese, Flynn postula que o objetivo do Livro de Jonas é demonstrar a universalidade de Yahweh, essa seria a "percepção pós-exílica", e que Jonas não compreende este propósito, ignorando que, mesmo no sheol, Yahweh está presente (A nossa historiografia subentendeu que o propósito do livro passa por esse aspecto teológico, mas o propósito é bem mais amplo, sendo o livro mais inovador e rico de confluências históricas do que o explanado pela teologia de Flynn).

Em adição, a identidade compartilhada transfere, primeiro para a tripulação da barca e em seguida para os ninivitas, o sinal de unidade política representado por Yahweh nas comunidades judaicas do período persa. O contexto da interpretação teológica, muito bem postulado por Erhard Gerstenberger (2014, p. 433-40, 504-09), leva-nos a uma tradição que soa como contraparte antimonárquica das destruições imperiais, como possibilidade de preservação da vida e de relacionamentos interétnicos tanto para os povos das bordas quanto para os povos das metrópoles. Eis, portanto, o nascimento de tradição profética motivada por voto em favor de Nínive, mas que de forma perspicaz está destinada à sobrevivência de populações economicamente fracas!

11 Jonas 3.6 como terceira via de informação, acerca do rei, foi colocado posteriormente à ação da população, em Jonas 3.5; a justificativa para o versículo 5 está em outra glosa, em 3.7. O agravamento do padrão pode ser conferido também em relação à glosa acerca da demografia da cidade, em Jonas 4.11. Na ficção profética, toda informação dispensa a verificação porque a cultura material é somente alcançada por fontes externas.

12 Cf. Jonas 1.14. 
Antimonárquica, nada tem a ver com as legislações excludentes do comissário persa Esdras - esse é outro partido político-sacerdotal! -, nenhuma relação com Davi e Salomão, além de distante da linha traçada pelos teólogos de Jerusalém. A questão é que estamos diante de uma "teologia da unidade", como descobriu Gerstenberger (2014, p. 435), "na Mesopotâmia, os judeus aprenderam a pensar universalmente", por isso o 'ibr 13 $^{13}$ permite-se com Jonas omitir o local de nascimento, a origem familial e a profissão, optando por apresentar a Yahweh como sua carta identitária. ${ }^{14}$ Inexiste debate acerca de algum panteão ou religião - não ignoramos os ambientes religiosos judaicos com suas noções de fé e práticas de culto! -, os fatos linguísticos a que se situa a atividade de Jonas são eminentemente políticos.

\section{Conclusão}

O ensaio cumpriu a função de fornecer elementos e contextos do Livro de Jonas numa pesquisa historiográfica, assumindo a profecia como ficcional, audível num itinerário geográfico que volta a iluminar o projeto do livro quando emerge do isolamento bíblico para fazer parte do mapa e dos movimentos vitais de populações e acontecimentos do antigo Oriente-Próximo. A profecia é, em parte, datada, seus panfletos encetam a universalidade de Yahweh, mas esta se torna inteligível no quadro político das comunidades religiosas do judaísmo que fazem parte da estrutura imperial persa. Jonas é um dos agentes sociais do amplo arco de elaborações e reelaborações ideológicas - conflitantes, de várias linguagens e que aludem aos problemas da convivência política e religiosa em curso nas províncias do entorno do rio Jordão. Em busca de legitimidade, os caráteres religiosos são invariavelmente retrospectivos, mas as exigências materiais do seu devido tempo presente fazem-nos mirar o futuro.

Enfatizemos: os domínios da atividade de Jonas devem ser buscados na política de sua época - nela encontraremos as culturas! -, sem ignorar sobretudo o domínio do império neoassírio de um mundo retroprojetado literariamente.

Dividimos nossa pesquisa em três etapas: a história social, a redação do livro, e os postulados teológicos das duas primeiras etapas. Entendemos que assim foram contornadas as interpretações tradicionais - tiramos o archote de sobre o animal marinho e de Jonas, fontes de distrações diversas -, e por isso apresentamos a denúncia profética da história em seus devidos contextos.

\footnotetext{
13 Povo seminômade que tem por origem um "aramita fugitivo" (cf. Deuteronômio 26.5; Salmo 39.13 [39.12]).

14 Assim em Jonas 1.9.
} 


\section{Referências bibliográficas}

ALONSO SCHÖKEL, Luís; SICRE DÍAZ, José Luiz. Profetas II: Ezequiel, Profetas Menores, Daniel, Baruc e Carta de Jeremias. Trad. Anacleto Alvarez. São Paulo: Paulinas 1991.

BAKKER, Maria Alice Biscaro de. A justiça e a misericórdia como mensagem de salvação universal: análise exegética de Jn 4.1-11 em seu contexto histórico e literário. Dissertação (Mestrado em Teologia Bíblica). Pontifícia Universidade Católica do Rio de Janeiro, Rio de Janeiro, 2010.

CANDIDO, Antonio. Literatura e sociedade: estudos de teoria e história literária. 12. ed. Rio de Janeiro: Ouro sobre Azul, 2011.

DAY, John. Where was Tarshish? In: PROVAN, Iain; BODA, Mark (eds.). Let us go up to Zion. Essays in honour of H.G.M. Williamson on the occasion of his sixty-fifth birthday. (Vetus Testamentum Supplements 153). Leiden: E.J. Brill, 2012, p. 359-369.

ELLIGER, Karl; RUDOLPH, Wilhelm (hrsg.). Biblia Hebraica Stuttgartensia. 5. aufl. Stuttgart: Deutsche Bibelgesellschaft, 1997.

FEUILLET, André. Les sources du Livre de Jonas. Revue Biblique, Paris, v. 54, n. 2, p. 161 186, 1947.

FLYNN, Shawn W. A story of Yhwh: cultural translation and subversive reception in Israelite history. (Studies in the History of the Ancient Near East). London: Routledge, 2020.

GERSTENBERGER, Erhard S. Israel no tempo dos persas: séculos V e IV antes de Cristo. Trad. Cesar Ribas Cezar. São Paulo: Loyola, 2014.

KAEFER, José Ademar. Novelas bíblicas. Caminhando, São Bernardo do Campo, v. 24, n. 1, p. 23-48, 2019.

KILLP, Nelson. Jonas. São Paulo: Loyola, 2008.

LIMBURG, James. Jonab: a commentary. Louisville: Westminster John Knox Press, 1993.

LION, Brigitte; MARGUERON, Jean-Claude. De la bourgade à la mégapole: Babylone et Ninive, réalités et imaginaire. In: BORDREUIL, Pierre; BRIQUEL-CHATONNET, Françoise; MICHEL, Cécile (dir.). Les débuts de l'Histoire: civilisations et cultures du Proche-Orient ancien. Nouvelle edition revue et augmentee. Paris: Éditions Khéops, 2014, p. 122-128.

LIPIŃSKI, Edward. Hiram of Tyre and Salomon. In: LEMAIRE, André; HALPERN, Baruch (eds.). The Books of Kings: sources, composition, historiography, and reception. (Vetus Testamentum Supplements 129). Atlanta, GA: SBL Press, 2010, p. 251-272.

MAGALHÃES, Antonio. A Bíblia como obra literária: hermenêutica literária dos textos bíblicos em diálogo com a teologia. In: SALMA, Ferraz; MAGALHÃES, Antonio; CONCEIÇÃO, Douglas; BRANDÃO, Eli; TENÓRIO, Waldecy (orgs.). Deuses em poética: estudos de literatura e teologia. Belém; Campina Grande: Editora da UEPA; Editora da UEPB, 2008, p. 11-24.

MIEROOP, Marc van de. Historia del Próximo Oriente antiguo: ca. 3000-323 A.E.C. Trad. Andrés Piquer y Sara Arroyo. Madrid: Trotta, 2020.

NISSINEN, Martti. Ancient prophecy: Near Eastern, biblical, and Greek perspectives.

Oxford: Oxford University Press, 2017. 
SANTOS, João Batista Ribeiro. Pertinências entre os anais egípcios e a biografia antiga: ensaio historiográfico sobre escrita e ideologia nas inscrições cuneiformes e hieroglíficas de eventos oficiais e memoriais do Egito antigo. Em Tempo de Histórias, Brasília, n. 23, p. 7-21, 2013.

SANTOS, João Batista Ribeiro; COSTA, Taís Dias da; CAMARGO, Wesley Magalini de; SILVEIRA, Leandro Gonçalves. O elogio retórico: uma análise literária do Salmo do livro de Yônāh. Caminhando, São Bernardo do Campo, v. 21, n. 2, p. 75-90, 2016.

SCHWANTES, Milton. Convite a compaixão: interpretação e meditação a partir de Jonas 4.1-11. Caminhando, São Bernardo do Campo, v. 11, n. 18, p. 13-24, 2006.

SILVA, Cássio Murilo Dias da. Leia a Bíblia como literatura. São Paulo: Loyola, 2007.

THOMASON, Allison Karmel. From Sennacherib's bronzes to Taharqa's feet: conceptions of the material world at Nineveh. Iraq, London, v. 66, p. 151-162, 2004. [On-line: Cambridge, 2014].

VAILATTI, Carlos Augusto. Jonas: introdução, tradução e comentário. São Paulo: Reflexão, 2018.

WOLFF, Hans Walter. Obadiah and Jonah: a commentary. Minneapolis: Augsburg Fortress, 1986. 